Brit. F. vener. Dis. (1967), 43, 170.

\title{
TREATMENT OF RELAPSES AND RE-INFECTIONS IN NON-SPECIFIC URETHRITIS
}

\author{
BY \\ A. I. MORRISON \\ Special Treatment Centre, Barnsley, Yorks.
}

The causes of non-specific urethritis (NSU) or "abacterial urethritis" have not yet been established. Many investigations have been carried out over a long period of time in attempts to find an organism causing this condition; these investigations include the following:

(A) Mycoplasma (PPLO) Dienes and Smith (1942); Smith (1942); Harkness (1950); Nicol and Edward (1953); Klieneberger-Nobel (1959); Shepard (1954, 1956, 1957, 1958, 1959, 1960); Röckl (1961); Csonka, Williams, and Corse (1966).

(B) Haemophilus vaginalis The role of this group in genital inflammation was reviewed by Lapage (1961).

(C) Anaerobic Organisms These were investigated by Morrison (1963). Attempts to culture anaerobic organisms were unsuccessful.

(D) Viruses Since Lindner (1910) first described elementary bodies in a urethral discharge, various attempts have been made to prove a viral aetiology by various workers including Halberstaedter and von Prowazek (1910); Thygeson and Mengert (1936); Harkness (1945); Johnston and McEwin (1945); Williams (1946); Dunlop, Jones, and Al-Hussaini (1964); Dunlop, Harper, Al-Hussaini, Garland, Treharne, and Wright (1966); Harper (1966).

(E) Allergy Weston (1965).

So far these efforts have proved unsuccessful or suggestive only, hence the empirical nature of the treatment of this condition. Many drugs, alone or in various combinations, are in use or have been tried; these include antibiotics, sulphonamides singly or combined, and potassium citrate mixture. Anterior irrigations alone or with these preparations are advocated. Corticosteroids have been tried by Ambrose and Taylor (1953), Grimble and Csonka (1955), and Willcox (1959). Anti-viral agents were tried by Duncan and Morton (1962) and LloydDavies (1962).
To assess the efficacy of different drugs used to treat NSU an attempt was made to find:

(1) The effect of the same or a different drug if the patient had a recurrence or relapse;

(2) Whether the same drug was used in patients with a past history of NSU:

(a) with the same consort

(b) with a different consort

\section{Material}

The series comprised 310 European male patients, average age 29.3 years (range 17 to 75 ); 171 were single, and 53 of the 139 married men admitted extramarital intercourse (38.12 per cent.). There were 64 contacts from 59 patients, and twenty ( 31 per cent.) were the wives of patients.

Only patients treated with antibiotics were included in the investigation. Altogether 41 cases were excluded (see Table I), leaving a final total of 269 cases which are reviewed below.

TABLE I

PATIENTS EXCLUDED FROM SURVEY

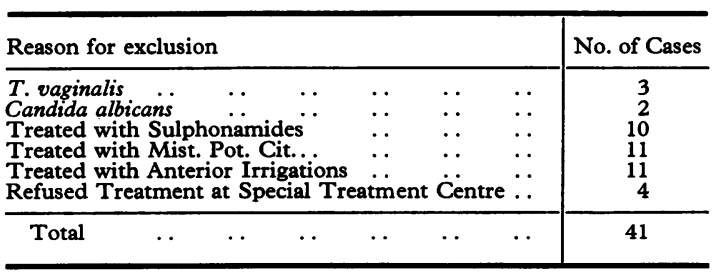

Management

Stained and wet films of the urethral discharge were examined to exclude gonorrhoea, Candida albicans, and $T$. vaginalis. A film and culture taken on a charcoalimpregnated swab were sent in Stuart's medium to the laboratory for confirmation. Urine from each patient was tested for albumin and sugar; hazy urines were centrifuged and examined in the clinic by wet and dry films and the deposit was cultured. Routine serological tests for syphilis were carried out on all patients. Not less than 28 days after the discharge had stopped, wet and stained films of prostatic secretion 
were examined. The results were also confirmed in the laboratory by film and culture. Whenever possible the patients were examined by urethroscopy before discharge (Morrison, 1965). The criteria for a satisfactory response were: no recurrence of urethral discharge after it had stopped, negative prostatic smears and cultures after 28 days, and clear urine in the two-glass test.

\section{Treatment}

The drugs used for the 269 cases are set out in Table II. It should be noted that the 25 patients treated with penicillin formed part of a series designed to test the effect of this antibiotic in the treatment of NSU (Morton and Morrison, 1963).

TABLE II

DRUGS USED IN 269 CASES

\begin{tabular}{|c|c|c|c|}
\hline \multicolumn{2}{|l|}{ Drugs Used } & \multicolumn{2}{|c|}{ No. of Cases } \\
\hline $\begin{array}{l}\text { Streptomycin } \\
\text { Oxytetracycline } \\
\text { Penicillin }\end{array}$ & $\begin{array}{l}\text { ( } 1 \text { g. daily for } 4 \text { days) } \\
(250 \mathrm{mg} \text {. 6-hrly for } 4 \text { days) }\end{array}$ & $\left.\begin{array}{r}170 \\
55 \\
25\end{array}\right\}$ & 250 \\
\hline $\begin{array}{l}\text { Miscellaneous } \\
\text { (Treated before } \\
\text { attending Special } \\
\text { Treatment Centre) }\end{array}$ & 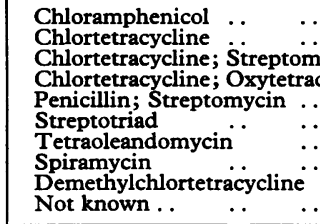 & $\begin{array}{c}\cdots \\
\cdots \\
\cdots \\
\cdots \\
\cdots \\
\cdots \\
\cdots\end{array}$ & $\left.\begin{array}{l}2 \\
5 \\
1 \\
1 \\
1 \\
1 \\
1 \\
1 \\
1 \\
5\end{array}\right\} 19$ \\
\hline & Total & & 269 \\
\hline
\end{tabular}

\section{Relapses}

A patient was considered to have relapsed if the urethral discharge recurred within 14 days after it had stopped and further exposure to risk was denied. Of 28 patients who relapsed, eleven had a past history of NSU and seventeen relapsed in their first infection. Three of the latter (Cases A,
$B$, and C) relapsed in a subsequent infection (Tables III and IV).

TABLE III

SEVENTEEN PATIENTS RELAPSING IN FIRST ATTACK OF NSU

\begin{tabular}{|c|c|c|c|}
\hline \multicolumn{2}{|c|}{ Drug evoking no Response } & \multicolumn{2}{|l|}{ Drug evoking Response } \\
\hline Streptomycin & 8 & $\begin{array}{l}\text { Streptomycin repeated } \\
\text { Oxyytetracycline (including C) } \\
\text { Chlortetracycline } \\
\text { Penicillin after Oxytetracycline } \\
\text { failure (B) }\end{array}$ & $\begin{array}{l}2 \\
4 \\
1 \\
1\end{array}$ \\
\hline Oxytetracycline & 2 & $\begin{array}{l}\text { Oxytetracycline repeated (A) } \\
\text { Tetraoleandomycin }\end{array}$ & 1 \\
\hline Penicillin & 6 & $\begin{array}{l}\text { Streptomycin } \\
\text { Oxytetramycin } \\
\text { Demethylchlortetracycline } \\
\text { after Oxytetracycline failure }\end{array}$ & $\begin{array}{l}2 \\
3 \\
1\end{array}$ \\
\hline $\begin{array}{l}\text { Treated at Sea } \\
\text { ? Treatment }\end{array}$ & 1 & Oxytetracycline & 1 \\
\hline Total & 17 & Total & 17 \\
\hline
\end{tabular}

Cases $\mathrm{A}, \mathrm{B}$, and $\mathrm{C}$ also relapsed in a subsequent infection (see Table IV).

\section{Summary of Treatment of 28 Relapses}

$\left.\begin{array}{c|lr}\hline \begin{array}{c}\text { Same Drug } \\ \text { Repeated }\end{array} & \text { Streptomycin } & 4 \\ & \text { Oxytetracycline } & 2\end{array}\right\} 6$

Contacts

Three with one contact

$$
\left\{\begin{array}{c}
1 \text { responded to the } \\
\text { same drug } \\
2 \text { did not respond }
\end{array}\right.
$$

TABLE IV

RELAPSES IN ELEVEN PATIENTS WITH PAST HISTORY OF NSU

\begin{tabular}{|c|c|c|c|}
\hline Infection in which Relapse Occurred & Treatment & Treatment of Relapse & Contact \\
\hline 1st and 2 nd & $\begin{array}{l}\text { 1st Oxytetracycline } \\
\text { 2nd Streptomycin }\end{array}$ & $\begin{array}{l}\text { Oxytetracycline repeated } \\
\text { Demethylchlortetracycline }\end{array}$ & Different \\
\hline (h) 1 st and 3 rd & $\begin{array}{l}\text { 1st Streptomycin } \\
\text { 3rd Streptomycin }\end{array}$ & $\begin{array}{l}\text { Oxytetracycline and Penicillin } \\
\text { Oxytetracycline }\end{array}$ & Different \\
\hline (l) $1 \mathrm{st}-9 \mathrm{th}$ & Streptomycin & Oxytetracycline & Different \\
\hline $\begin{array}{l}\text { 2nd-1st Streptomycin } \\
\text { 2nd-1st Penicillin } \\
\text { 2nd-1st Penicillin }\end{array}$ & $\begin{array}{l}\text { Penicillin } \\
\text { Penicillin } \\
\text { Streptomycin }\end{array}$ & $\begin{array}{l}\text { Streptomycin } \\
\text { Demethylchlortetracycline } \\
\text { Oxytetracycline }\end{array}$ & $\begin{array}{l}\text { Different } \\
\text { Different } \\
\text { Different }\end{array}$ \\
\hline (k) 3rd and 4th & $\begin{array}{l}\text { 3rd Penicillin } \\
\text { 4th Streptomycin }\end{array}$ & $\begin{array}{l}\text { Oxytetracycline } \\
\text { Oxytetracycline }\end{array}$ & Same \\
\hline (g) 3rd and 4th & $\begin{array}{l}\text { Streptomycin } \\
\text { Streptomycin }\end{array}$ & $\begin{array}{l}\text { Streptomycin repeated } \\
\text { Streptomycin repeated }\end{array}$ & Different \\
\hline (e) 4th & Penicillin & Demethylchlortetracycline & Same \\
\hline
\end{tabular}




\begin{tabular}{|c|c|}
\hline $\begin{array}{l}\text { Six with different } \\
\text { contacts }\end{array}$ & $\begin{array}{l}1 \text { responded to the } \\
\text { same drug } \\
5 \text { responded to } \\
\text { different drugs }\end{array}$ \\
\hline \multicolumn{2}{|l|}{ Percentages of Relapses } \\
\hline Series as a whole & $28 / 269$ (10.40 per cent. $)$ \\
\hline Relapsed in first & $17 /$ \\
\hline Past history of NSU & $11 / 104$ (10.57 per cent.) \\
\hline
\end{tabular}

There is thus no difference between the two groups and both are equal as regards the overall percentage. These figures are very close to the $11 \cdot 6$ per cent. obtained by Morton and Read (1957).

\section{Re-infections}

The 42 patients involved are shown in Table V.

TABLE V

RE-INFECTIONS IN 42 PATIENTS

\begin{tabular}{|c|c|c|c|}
\hline \multicolumn{2}{|c|}{ No. of Patients } & $\begin{array}{l}\text { No. of Attacks of } \\
\text { NSU each }\end{array}$ & $\begin{array}{c}\text { Total Attacks of } \\
\text { NSU }\end{array}$ \\
\hline & 30 & 2 & 60 \\
\hline 12 & $\begin{array}{l}4 \\
5 \\
1 \\
1 \\
1\end{array}$ & $\begin{array}{r}3 \\
4 \\
5 \\
6 \\
11\end{array}$ & $\begin{array}{r}12 \\
20 \\
5 \\
6 \\
11\end{array}$ \\
\hline & $42^{*}$ & & 114 \\
\hline
\end{tabular}

*Four had had gonorrhoea, one had congenital syphilis, one had had secondary syphilis.

Contacts Of the thirty patients having two attacks of NSU, fifteen had one contact; nine of these responded to the same drug on both occasions and six responded to a different drug. The other fifteen had different contacts; five responded to the same drug and ten responded to different drugs.

For the twelve patients with three or more infections the details of treatment, relapses, and contacts are shown in Table VI (opposite).

\section{Summary of Repeated Re-infections in Twelve Cases ( $a$ to $l$ ) (Table VI)}

Cases $a, b$, and $c$ One contact each. Responded to streptomycin in each of three infections.

Case $d \quad$ Two contacts. First infection (1) responded to penicillin, second and third (2) both responded to streptomycin.

Case $e$ One contact. First, second, and third infections responded to penicillin, tetraoleandomycin, and oxytetracycline respectively. Fourth relapsed with penicillin but responded to demethylchlortetracycline.

Case $f$ Two contacts. First (1) and fourth (2) responded to oxytetracycline, second (2) and third (2) to streptomycin.
Case $g$ Four contacts. (1) responded to streptomycin; (2) to oxytetracycline; (3) and (4) relapsed with streptomycin but responded to a second course of the same drug.

Case $h \quad$ Three contacts. First infection after exposure with both (1) and (2) relapsed twice with streptomycin and oxytetracycline and responded to penicillin. Second and fourth (3) treated with streptomycin. Third (3) relapsed but responded to oxytetracycline.

Case $i \quad$ Four contacts. First (1) and third (3) responded to oxytetracycline, second (2) and fourth (4) to streptomycin.

Case $j$ One contact. Five infections each responded to streptomycin.

Case $k$ One contact. First, second, and fifth responded to streptomycin. Fourth relapsed with streptomycin, and was treated with oxytetracycline. Sixth responded to penicillin. Third did not respond to penicillin and was treated with oxytetracycline.

Case $l$ Two contacts. First infection (1) and (2) treated with streptomycin, relapsed, and was treated with oxytetracycline. Second and third (1) responded to oxytetracycline. Fourth and fifth (1) treated with penicillin. The patient married contact (2) and had six more infections; the sixth was treated with oxytetracycline, and the seventh to eleventh all with streptomycin. The ninth relapsed and was treated with aureomycin.

\section{Relapses}

\section{Results}

(1) First Infection The drug was changed in fourteen of the seventeen patients who relapsed in their first infection. Three patients responded to a second course of treatment with the original drug.

(2) Past History of NSU

(A) ONE CONSORT

$e$. Treated with different drugs, but relapsed in the fourth infection.

$k$. One drug was used to treat his two relapses; another drug was used successfully in three of his six infections.

(B) DifFerent Consorts

g. Two relapses responded to repeated courses of the original drug.

$h$. First infection relapsed twice after a double exposure. Two of three other infections with the same contact responded to the same drug.

\section{Re-infections}

\section{(A) ONE CONSORT}

$a, b, c$, and $d$. Responded to the same drug.

$e$. Responded to a different drug.

$k$. Responded to the same drug in three of four infections. 
TABLE VI

RE-INFECTIONS IN TWELVE PATIENTS ( $a$ to $l$ ) WITH THREE OR MORE INFECTIONS

\begin{tabular}{|c|c|c|c|c|c|c|c|c|}
\hline \multirow[b]{2}{*}{ Patient } & \multirow{2}{*}{$\begin{array}{l}\text { No. of } \\
\text { Contacts }\end{array}$} & \multicolumn{7}{|c|}{ Treatment for Each Infection (Contact No. shown in Brackets) } \\
\hline & & $1 \mathrm{st}$ & 2nd & 3rd & 4th & 5 th & 6 th & 7th-11th \\
\hline$a$ & 1 & $\begin{array}{l}\text { (1) } \\
\text { Streptomycin }\end{array}$ & $\begin{array}{r}(1) \\
\text { Streptomycin }\end{array}$ & $\begin{array}{r}\text { (1) } \\
\text { Streptomycin }\end{array}$ & & & & \\
\hline$b$ & 1 & Streptomycin & Streptomycin & $\begin{array}{r}\text { (1) } \\
\text { Streptomycin }\end{array}$ & & & & \\
\hline$c$ & 1 & $\begin{array}{r}(1) \\
\text { Streptomycin }\end{array}$ & Streptomycin & $\begin{array}{r}(1) \\
\text { Streptomycin }\end{array}$ & & & & \\
\hline$d$ & 2 & Penicillin (1) & $\begin{array}{l}(2) \\
\text { Streptomycin }\end{array}$ & $\begin{array}{r}(2) \\
\text { Streptomycin }\end{array}$ & & & & \\
\hline$e$ & 1 & Penicillin (1) & $\begin{array}{c}\text { Tetraoleando- } \\
\text { mycin }\end{array}$ & $\begin{array}{c}\text { Oxytetra- } \\
\text { cycline }\end{array}$ & $\begin{array}{l}\text { Penicillin } \\
\text { Ledermycin } \\
\begin{array}{c}\text { Demethylchlor- } \\
\text { tetracycline }\end{array}\end{array}$ & & & \\
\hline$f$ & 2 & $\begin{array}{c}\text { Oxytetra- } \\
\text { cycline }\end{array}$ & $\begin{array}{l}\text { (2) } \\
\text { Streptomycin }\end{array}$ & $\begin{array}{r}(2) \\
\text { Streptomycin }\end{array}$ & Oxytetracycline & & & \\
\hline$g$ & 4 & $\begin{array}{l}(1) \\
\text { Streptomycin }\end{array}$ & $\begin{array}{c}\text { Oxytetra- } \\
\text { cycline }\end{array}$ & $\begin{array}{l}\text { (3) } \\
\text { Streptomycin } \\
\times 2\end{array}$ & $\underset{\times 2}{\text { Streptomycin }}$ & & & \\
\hline$h$ & 3 & $\begin{array}{l}\quad(1) \text { and }(2) \\
\text { Streptomycin } \\
\text { Oxytetra- } \\
\text { cycline } \\
\text { Penicillin } \\
\end{array}$ & Streptomycin & $\begin{array}{l}\text { Streptomycin } \\
\text { Oxytetra- } \\
\text { cycline }\end{array}$ & Streptomycin & & & \\
\hline$i$ & 4 & $\begin{array}{c}\text { Oxytetra- } \\
\text { cycline }\end{array}$ & Streptomycin & $\begin{array}{c}\text { Oxytetra- } \\
\text { cycline }\end{array}$ & Streptomycin & & & \\
\hline$j$ & 1 & $\begin{array}{c}(1) \\
\text { Streptomycin } \\
\end{array}$ & $\begin{array}{r}(1) \\
\text { Streptomycin }\end{array}$ & $\begin{array}{r}(1) \\
\text { Streptomycin }\end{array}$ & Streptomycin $^{(1)}$ & $\begin{array}{r}(1) \\
\text { Streptomycin }\end{array}$ & & \\
\hline$k$ & 1 & $\begin{array}{l}(1) \\
\text { Streptomycin }\end{array}$ & $\begin{array}{l}(1) \\
\text { Streptomycin }\end{array}$ & $\begin{array}{c}\text { Penicillin } \\
\text { Oxytetra- } \\
\text { cycline }\end{array}$ & $\begin{array}{l}\text { Streptomycin } \\
\text { Oxytetracycline }\end{array}$ & Streptomycin & Penicillin (1) & \\
\hline$l$ & 2 & $\begin{array}{l}\text { (1) and (2) } \\
\text { Streptomycin } \\
\text { Oxytetra- } \\
\text { cycline }\end{array}$ & $\begin{array}{c}\text { Oxytetra- } \\
\text { cycline }\end{array}$ & $\begin{array}{c}\text { Oxytetra- } \\
\text { cycline }\end{array}$ & Penicillin (1) & Penicillin (1) & $\begin{array}{l}\text { (2) (wife) } \\
\text { Oxytetra- } \\
\text { cycline }\end{array}$ & $\begin{array}{l}\text { (2) } \\
\text { Streptomycin } \\
\text { 9th relapsed } \\
\text { and was treated } \\
\text { with Chlor- } \\
\text { tetracycline }\end{array}$ \\
\hline
\end{tabular}

(B) Different Consorts

$d$ and $f$. Responded to different drugs. $g$. Responded to a different drug and the same drug repeated.

$h$. Two of three infections from the same contact responded to the same drug.

$i$. Two preparations twice used successfully after four contacts.

l. After exposure with one of two contacts, responded to two drugs; after five exposures with the other contact, one drug was used successfully four times (see Relapses).

\section{Discussion}

The empirical treatment of a condition of unknown origin may be one reason for the increase of non-specific urethritis. There has been a rise in the incidence of this disease since 1951 when the number of cases was first reported separately to the Ministry of Health by clinics in England and Wales.

It may be possible to distinguish between relapses and re-infections of NSU if exposure to re-infection is denied. A time basis must then be used to decide between them. An arbitrary period of 14 days was used and this chanced to coincide with the 8 to 14 days considered as the probable true incubation period of NSU (King, 1964, p. 363).

An attempt was made to assess the efficacy of antibiotic drugs in the treatment of relapses and re-infections of NSU by the same or different consorts. Tables IV and VI suggest that infections acquired from the same consort will respond to the same drug, and that infections from different consorts respond to different drugs. 
A large series of patients in whom the treatment is carefully controlled with regard to the treatment of relapses or re-infections by the same or different contacts may shed more light on this matter.

\section{Summary}

In a series of 269 cases of NSU, 28 patients relapsed; seventeen of these were in their first infection, and three of these relapsed again in a subsequent infection. Eleven cases of relapse had a past history of NSU. There were 114 infections in 42 cases (i.e. 72 re-infections), and most responded to the same drug when infected by the same consort.

Re-infections by a different consort and also relapses apparently respond to a change in drug.

\section{REFERENCES}

Ambrose, S. S., and Taylor, W. W. (1953). Amer. F. Syph., 37, 501.

Csonka, G. W., Williams, R. E. O., and Corse, J. (1966). Lancet, 1, 1292.

Dienes, L., and Smith, W. E. (1942). Proc. Soc. exp. Biol. (N.Y.), 50, 99.

Duncan, W. A. M., and Morton, R. S. (1962). Brit. F. vener. Dis., 38, 64.

Dunlop, E. M. C., Harper, I. A., Al-Hussaini, M. K., Garland, J. A. R., Treharne, J. D., and Wright, D. J. M. (1966). Ibid., 42, 77.

- Jones, B. R., and Al-Hussaini, M. K. (1964). Ibid., 40, 33.

Grimble, A., and Csonka, G. W. (1955). Ibid., 31, 228.

Halberstaedter, L., and Prowazek, S. von (1910). Berl. klin Wschr., 47, 661.

Harkness, A. H. (1945). Brit. F. vener. Dis., 21, 93.

- (1950). "Non-Gonococcal Urethritis", p. 27. Livingstone, Edinburgh.

Harper, I. A. (1966). Brit. Э. vener. Dis., 42, 71.

Johnston, G. A. W., and McEwin, J. (1945). Med. F. Aust., 1, 368.
King, A. J. (1964). "Recent Advances in Venereology", p. 353. Churchill, London.

Klieneberger-Nobel, E. (1959). Brit. med. F., 1, 19.

Lapage, S. P. (1961). Acta path. microbiol. scand , 52, 34.

Lindner, K. (1910). Wien. klin. Wschr., 23, 283.

Lloyd-Davies, R. W. (1962). Brit. F. vener. Dis., 38, 69. Morrison, A. I. (1963). Ibid., 39, 118. (1965). Ibid., 41, 132.

Morton, R. S., and Morrison, A. I. (1963). Ibid., 39, 244.

1 and Read, L. (1957). Ibid., 33, 223.

Nicol, C. S., and Edward, D. G. ff. (1953). Ibid., 29, 141.

Röckl, H. (1961). Arch. klin. exp. Derm., 213, 819.

Shepard, M. C. (1954). Amer. F. Syph., 38, 113.

- (1956). F. Bact., 71, 362.

- (1957). Ibid., 73, 162.

- (1958). Ibid., 75, 351 .

- (1959). Urol. int. (Basel), 9, 252.

- (1960). Ann. N.Y. Acad. Sci., 79, 397.

Smith, W. E. (1942). F. Bact., 43, 83.

Thygeson, P., and Mengert, W. F. (1936). Arch. Ophthal. (Chicago), 15, 377.

Weston, T. E. T. (1965). Brit. F. vener. Dis., 41, 107.

Willcox, R. R. (1959). Ibid., 35, 264.

Williams, S. (1946). Med.F. Aust., 1, 693.

\section{Le traitement des rechutes et des réinfections dans les cas d'urétrite non-spécifique RÉSUMÉ}

Dans une série de 269 cas atteints d'urétrite nonspécifique 28 patients ont rechuté; 17 d'entre ceux-là étaient à leur première infection, et 3 des 17 ont rechuté de nouveau aprés une infection subséquente. Onze cas de rechutes avaient donné un historique d'urétrite non-spécifique antérieur.

Il y avait eu 114 infections chez 42 cas (i.e. 72 réinfections); la plupart ont répondu au même médicament quand l'infection avait été causée par le même consort. La réinfection par un autre consort et aussi les rechutes semblaient répondre quand un autre médicament était employé. 